\title{
Diversity of sponge-associated fungi from a mangrove forest in Kemujan Island, Karimunjawa National Park, Indonesia
}

\author{
MADA TRIANDALA SIBERO ${ }^{1,2, \boldsymbol{v}}$, RUDHI PRIBADI ${ }^{1}$, STEFANIE JESSICA HENNY LARASATI ${ }^{1}$, \\ MARK S. CALABON ${ }^{3,4}$, AGUS SABDONO ${ }^{1}$, SUBAGIYO SUBAGIYO ${ }^{1}$, EVAN HANSEL FREDERICK ${ }^{1,2}$ \\ ${ }^{1}$ Department of Marine Science, Faculty of Fisheries and Marine Science, Universitas Diponegoro. Jl. Prof. Soedarto SH, Semarang 50275, Central Java, \\ Indonesia. Tel./fax.: +62-24-7474698, "email: madatriandalasibero@lecturer.undip.ac.id \\ ${ }^{2}$ Natural Product Laboratory, Integrated Laboratory for Research and Services, Universitas Diponegoro. Jl. Prof. Soedarto SH, Semarang 50275, Central \\ Java, Indonesia \\ ${ }^{3}$ Center of Excellence in Fungal Research, Mae Fah Luang University. 333 Moo1, Thasud, Muang, Chiang Rai 57100, Thailand \\ ${ }^{4}$ School of Science, Mae Fah Luang University. 333 Moo1, Thasud, Muang, Chiang Rai 57100, Thailand
}

Manuscript received: 9 November 2021. Revision accepted: 29 November 2021.

\begin{abstract}
Sibero MT, Pribadi R, Larasati SJH, Calabon MS, Sabdono A, Subagiyo S, Frederick EH. 2021. Diversity of spongeassociated fungi from a mangrove forest in Kemujan Island, Karimunjawa National Park, Indonesia. Biodiversitas 22: 5695-5605. Plenty of studies have reported interesting biological properties and bioactive compounds from sponge-associated fungi in Indonesia. However, only a few studies consider their biodiversity. Most of the studies collected the sponge from the coral reef ecosystem and barely reported from the mangrove ecosystem. This study aimed to discover the biodiversity of sponge-associated fungi from a mangrove ecosystem using a DNA barcoding approach. Five mangrove-associated sponges were collected from a tidal mangrove forest in Kemujan Island, Karimunjawa National Park, Indonesia. In total, we isolated 56 sponge-associated fungi, which consisted of seven genera in the phylum Ascomycota (77.78\%), one genus in the phylum Basidiomycota (11.11\%), and one genus in the phylum Mucoromycota (11.11\%). Trichoderma (n: 15, 26.79\%), Aspergillus (n: 13, 23.21\%) and Fusarium (n: 12, 21.45\%) were the top three dominant genera. In addition, based on the association of fungi to its sponge hosts, Aspergillus, Aureobasidium, Fusarium, and Trichoderma are sponge-generalists; Absidia and Pestalotiopsis are sponge-associates; while Lasiodiplodia, Montagnula, and Wallemia are sponge-specialist.
\end{abstract}

Keywords: DNA barcoding, marine facultative fungi, marine mycology, phylogeny, tropical mycology

\section{INTRODUCTION}

The marine sponge is an important invertebrate that helps the establishment of marine ecosystems since they provide shelter for other organisms, including microorganisms (Becking et al. 2013; Calcinai et al. 2017; Ismet et al. 2020). They also contribute to an enormous process in marine ecosystems (González-Rivero et al. 2011). Many studies have reported their role in reef ecosystems (González-Rivero et al. 2011; Bell et al. 2019), however, either sponge's biodiversity or ecological function in mangrove ecosystem is less reported, especially in Indonesia (Becking et al. 2013; Calcinai et al. 2017; Setiawan et al. 2019; Sibero et al. 2019). Vahidi et al. (2020) stated the physicochemical condition in a mangrove ecosystem significantly impacts the dispersion and diversity of associated invertebrates. They emphasized that the benthic fauna in coastal zone mangroves had the lowest diversity rather than deltaic and island zones. This fact is very interesting since several mangrove forests in Indonesia are located in the coastal zone, such as mangrove forests in Kemujan Island, Karimunjawa National Park. In addition, this location faces stresses from the fluctuating salinity, $\mathrm{pH}$, wave, tidal, current, and anthropogenic activity (Kamal et al. 2016; Puryono and Suryanti 2019; Hapsari et al. 2020). It leads to an understanding that mangrove sponges from the coastal zone are supposed to have a unique resilience strategy; thus, only particular genera or species can survive (Setiawan et al. 2018; Chakraborty 2019).

Further, sponge holobiont has a prominent function in maintaining sponge resilience in its habitat. Due to the filter-feeding behavior, the sponge hosts fungi and other microorganisms to establish its holobiont (Pita et al. 2018). Sponge-associated fungi are commonly reported as marinederived fungi. It means the fungi might originate from freshwater or terrestrial environments brought by the wind or water into the ocean then grow and possibly sporulate in seawater (Nguyen and Thomas 2018; Calabon et al. 2019; Sibero et al. 2019). These fungi are well known as potential producers of unique bioactive compounds with diverse biological properties (Imhoff 2016; Indraningrat et al. 2016). Our previous works successfully isolated some interesting novel compounds from Indonesia's spongeassociated fungi, such as karimunone A-B, karimanone, and penicitrinone G (Sibero et al. 2019; Sabdaningsih et al. 2020; Sibero et al. 2020). In addition to the potential for biotechnology, the study of biodiversity of spongeassociated fungi from Indonesia has been neglected and has not been explored. Nonetheless, biodiversity is correlated with its chemodiversity for biotechnological purposes (Bovio et al. 2019). 
The diversity of sponge-associated fungi is strongly connected to host species and their environmental conditions (Yang et al. 2019). This idea is supported by Nguyen and Thomas (2018) that found some sponges were host-specific to particular marine fungi. The diversity of sponge-associated fungi from the mangrove environment is rarely reported. Calabon et al. (2019) discovered Aspergillus and Penicillium were the most dominant genera in four mangrove-associated sponges from New Washington, Aklan in the Philippines. Nevertheless, the study did not perform molecular identification to confirm the species and lead to the description of plenty of morphospecies of sterile mycelium. In our previous study, molecular identification through DNA barcoding was conducted to verify the species of sponge-associated fungi from a mangrove sponge from Mangkang, Indonesia (Sibero et al. 2019). It was the first and the latest study of sponge-associated fungi from Indonesia's mangrove forest; however, there is no report about the diversity yet.

Due to the lack of information and high potential of sponge-associated fungi from the mangrove ecosystem in Indonesia, this research was conducted to isolate, identify and determine fungal diversity of mangrove-associated fungi from Kemujan Island, Karimunjawa National Park Indonesia. This research is fundamental to understanding the diversity and ecology of the neglected microbial biodiversity in Indonesia.

\section{MATERIALS AND METHODS}

\section{Sampling}

Sponge collection was conducted in April 2019 in Kemujan Island, Karimunjawa National Park, Central Java Indonesia (Figure 1). A purposive sampling method was applied to collect sponges attached to the living mangrove roots and bark along the coastal zone. Environmental parameters (temperature, $\mathrm{pH}$, salinity, dissolved oxygen), coordinate, and mangrove hosts were recorded to describe the habitat of the sponge.

\section{Fungal isolation}

Sponge-associated fungi from mangrove habitats were isolated according to the protocol that has been published in our previous work (Sibero et al. 2019). Potato dextrose agar (PDA) was prepared in natural seawater with $2 \%$ Chloramphenicol to eliminate bacterial growth. Sponges were washed using sterilized natural seawater followed by $70 \%$ alcohol, then rewashed using sterilized natural seawater. The mesohyl part was cut into three pieces, then put onto isolation media and incubated at $27^{\circ} \mathrm{C}$. Fungal growth was observed every day. Each mycelium grown on samples was transferred into new agar media as a single isolate. During fungal isolation, environmental control was prepared to decrease untargeted microbes, such as airborne fungi. Unfortunately, most of the collected sponges had a small size $(<4 \mathrm{~cm})$ due to the restriction of sampling in Karimunjawa National Park; hence sponge identification was not performed.
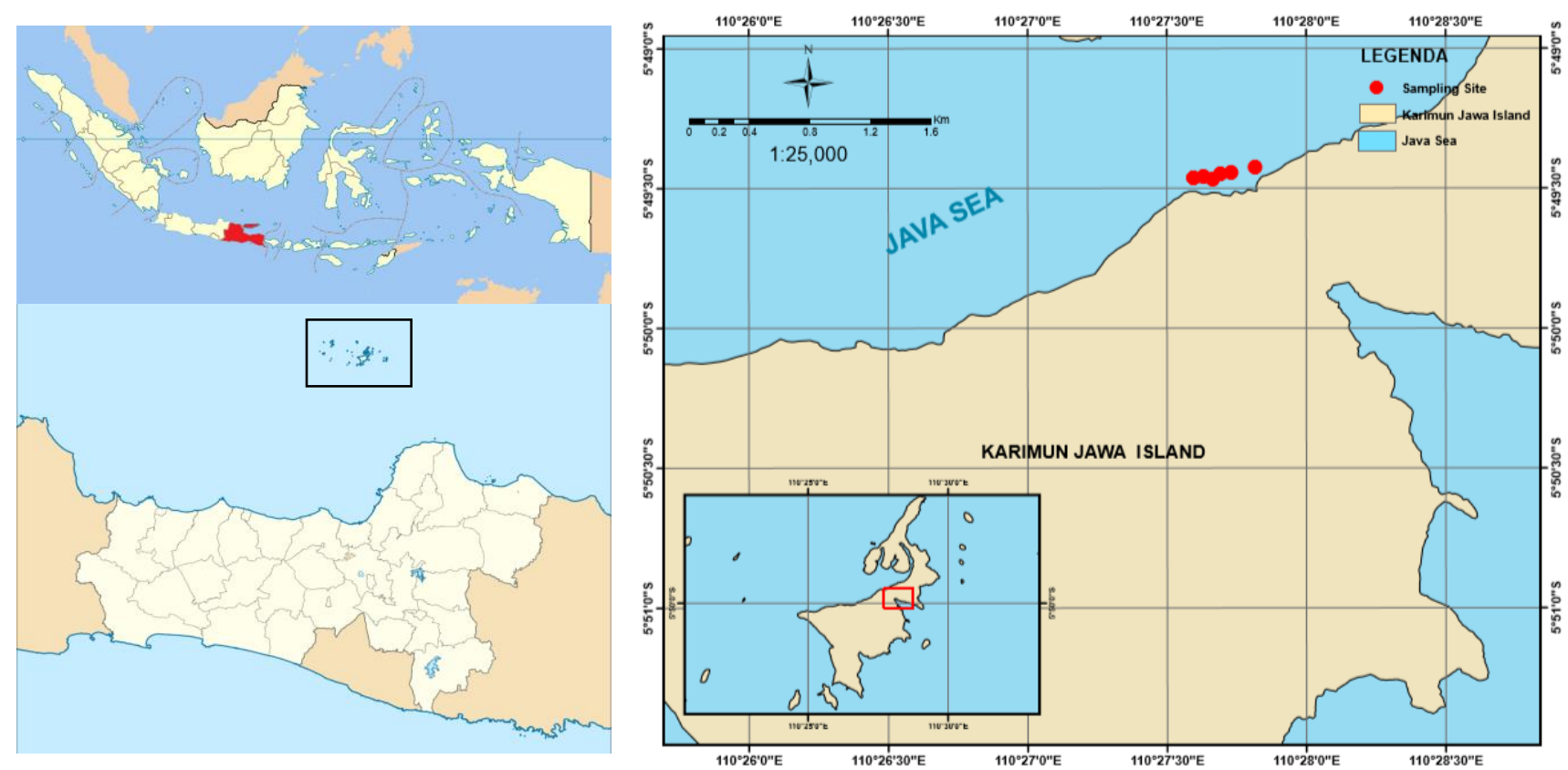

Figure 1. Location of sponge collection in Kemujan island, Karimunjawa National Park, Central Java, Indonesia 


\section{Fungal macro-microscopic characterization}

All filamentous fungi from mangrove-associated sponges were characterized according to their macroscopic (colonial) and microscopic characteristics. The macroscopic (colonial) characteristics included colonial color and texture, a soluble pigment in agar media, presence of exudate and sclerotia. On the other hand, the microscopic feature was observed by slide culture (Riddell 1950; Sibero et al. 2018) and tape touch methods (Harris 2000) with the addition of lactophenol cotton blue (HiMedia). Some microscopic descriptions included conidiophore, spore, phialides, hyphae, and vesicle (for Aspergillus spp.) were observed under a microscope. Every isolate with the same macroscopic and microscopic characteristics was co-cultured on the same Petri to observe the difference. Afterward, isolate with the same growth pattern and colonial characteristics without inhibition zone were expected as the same species. Furthermore, the isolate was expected as different species then identified through DNA barcoding to confirm the species.

\section{Fungal identification through DNA barcoding}

The isolates were cultivated for 4-7 days on PDA for DNA extraction using Quick-DNATM Fungal/Bacterial Miniprep Kit (D6005, Zymo Research). PCR protocol for DNA amplification was conducted according to Sibero et al. (2019). The PCR mixture consisted of $12.5 \mu \mathrm{L}$ PCR mix master (Promega), $1 \mu \mathrm{L}$ primer ITS1 (5'-TCC GTA GGT GAA CCT GCG G-3') (Macrogen), $1 \mu \mathrm{L}$ primer ITS4 (5'TCC TCC GCT TAT TGA TAT GC-3') (Macrogen), $1 \mu \mathrm{L}$ DNA template and $9.5 \mu \mathrm{L}$ of ddH2O with a final volume of $25 \mu \mathrm{L}$. The DNA in the PCR mixture was amplified using a thermal cycler with the following condition: denaturation at $95^{\circ} \mathrm{C}$ for $1 \mathrm{~min}$, annealing for $1 \mathrm{~min}$, and extension at $72^{\circ} \mathrm{C}$ for $1 \mathrm{~min}$. We highlighted that the annealing temperature for PCR protocol was various; therefore, temperature optimization for annealing was conducted. The quality of PCR products was checked using gel electrophoresis in $1 \%$ agarose gel then sent to 1st BASE DNA Laboratories Sdn Bhd, Malaysia for sequencing. The phylogenetic tree was reconstructed following Dissanayake et al. (2020).

\section{Data analysis}

Data analysis was conducted according to (Calabon et al. 2019). The total frequency of occurrence (FOC), fungal diversity, species dominance, evenness, and species similarity was analyzed.

The total frequency of occurrence (FOC) was calculated using these formulas:

$$
\text { Total FOC (\%): } \frac{\text { Number of presence }}{\text { Total sponge }} \times 100
$$

Frequency of occurrence (FOC) of species A (\%) per sponge species:

$$
\text { FOC per species (\%): } \frac{\text { No. of collections of species A }}{\text { Number of samples examined }} \times 100
$$

The fungal diversity was calculated according to Ludwig and Reynolds (1988).
Shannon Index $\left(\mathrm{H}^{\prime}\right)$

$$
\text { Shannon Index }\left(H^{\prime}\right)=-\Sigma(p i \ln p i)
$$

Where, pi refers to the proportion of individuals that species $\mathrm{i}$ contribute to the total number of individuals. pi value was obtained by using this following formula:

$$
p i=n i / N
$$

Where, ni refers to the number of individuals $i 1, i 2, i 3$, i4, ... ix; while $\mathrm{N}$ is the total number of individuals (records).

Simpson Index of Dominance (D)

$$
D=\Sigma p i 2
$$

Where, pi: proportion of individuals in the ith species.

The value of $\mathrm{D}$ is the opposite of diversity; when $\mathrm{D}$ score increases, the diversity decreases. This following calculation obtains the Simpson index of dominance:

$$
1-D \text { or } \frac{1}{D}
$$

Shannon Evenness ( $\left.\mathbf{J}^{\prime}\right)$

$$
I^{\prime}=\frac{H^{\prime}}{H_{\max }}
$$

Where, $H_{\max }$ refers to the maximum value of diversity for the number of species present.

Simpson's Evenness (E1/D)

$$
E_{l / D}=(1 / D) / S
$$

Where, D refers to Simpson' index of diversity while; $S$ refers to species richness.

Jaccard Index of Species Similarity

$$
I I=\frac{a}{(a+b+c)}
$$

Where, a refers to the number of fungal species occurring in both hosts; $b$ refers to the number of fungal species unique to the; $\mathrm{c}$ refers to the number of fungal species unique to the second host.

\section{RESULTS AND DISCUSSION}

The mangrove forest in Kemujan Island, Karimunjawa National Park, Central Java, Indonesia, is a conservation area to protect the coastal ecosystem and an ecotourism site due to its floral and faunal diversity (Puryono and Suryanti 2019; Winata et al. 2020). Previous studies reported mangrove zonation, diversity, and carbon stock from this location (Nehren and Wicaksono 2018; Winata et al. 2020). Some mangrove species such as Avicennia alba, A. marina, Bruguiera gymnorrhiza, Ceriops tagal, Rhizophora apiculata, R. mucronata, Sonneratia alba, and Xylocarpus 
granatum have been previously reported (Hapsari et al. 2020; Winata et al. 2020). Nonetheless, no study was ever conducted to report mangrove-associated sponges in the tracking mangrove Kemujan Island. Table 1 shows the mangrove-associated sponge, host species, and environmental conditions during the sampling, whereas specimen morphology is provided in Figure 2.

Interestingly, the current study found all sponge specimens associated with $R$. mucronata and grew on the root (KMS 1, 2, 5, and 13) or at the edge of the root to establish the lifeform (KMS 15). Apart from sample KMS 1 , other sponges were submerged during the low tide. Various factors such as currents, tides, and winds influenced the larval settlement in the marine ecosystem (Indrayanti et al. 2019). Rhizophora mucronata was noted as the outer species in the tracking mangrove Kemujan Island, Karimunjawa National Park. Due to the position, $R$. mucronata is directly exposed by the wind, current, and tides suggested to drive the larval settlement on its root. The number of mangrove-associated sponges is minimal.
Setiawan et al. (2019) also stated that sponge diversity in mangrove habitat was generally lower than in the shallowwater habitat. Unfortunately, sponge identification was not performed in this study because of the maximum sample size restriction since the sampling site is a conservation area.

Fungi produce spores, conidia, and aerial mycelia to help them scatter into the environment through the air (Després et al. 2012). The wind, raindrops, or other biological agents bring these vegetative cells then land in the aquatic environment include the marine ecosystem. According to their needs for salinity, there are two categories of marine fungi, namely marine facultative and marine obligate fungi. Fungi that grow and sporulate in marine and other environments without salinity are defined as marine-derived or marine facultative fungi. Meanwhile, fungi that strictly grow and sporulate only in the marine environment with salinity are defined as a marine obligate (Kohlmeyer and Kohlmeyer 1979; Imhoff 2016; Raghukumar 2017).

Table 1. Mangrove-associated sponge, host species, and environmental condition from tracking mangrove Kemujan Island, Karimunjawa National Park, Central Java, Indonesia

\begin{tabular}{llccccc}
\hline \multicolumn{1}{c}{ Sample } & Host & DO $(\mathbf{m g} / \mathbf{L})$ & Water temperature & Salinity $(\mathbf{p p m})$ & TDS $(\mathbf{m g} / \mathbf{L})$ & Depth $(\mathbf{c m})$ \\
\hline KMS 1 & Rhizophora mucronata & 5.25 & $32.3^{\circ} \mathrm{C}$ & 20 & 4.70 & 3.50 \\
KMS 2 & Rhizophora mucronata & 6.53 & $34.5^{\circ} \mathrm{C}$ & 25 & 6.53 & 12.50 \\
KMS 5 & Rhizophora mucronata & 5.76 & $32.4^{\circ} \mathrm{C}$ & 21 & 5.66 & 5.00 \\
KMS 13 & Rhizophora mucronata & 5.85 & $34.8^{\circ} \mathrm{C}$ & 23 & 7.07 & 7.10 \\
KMS 15 & Rhizophora mucronata & 6.53 & $34.5^{\circ} \mathrm{C}$ & 25 & 6.53 & 12.50 \\
\hline
\end{tabular}

Note: KMS: Kemujan Sample
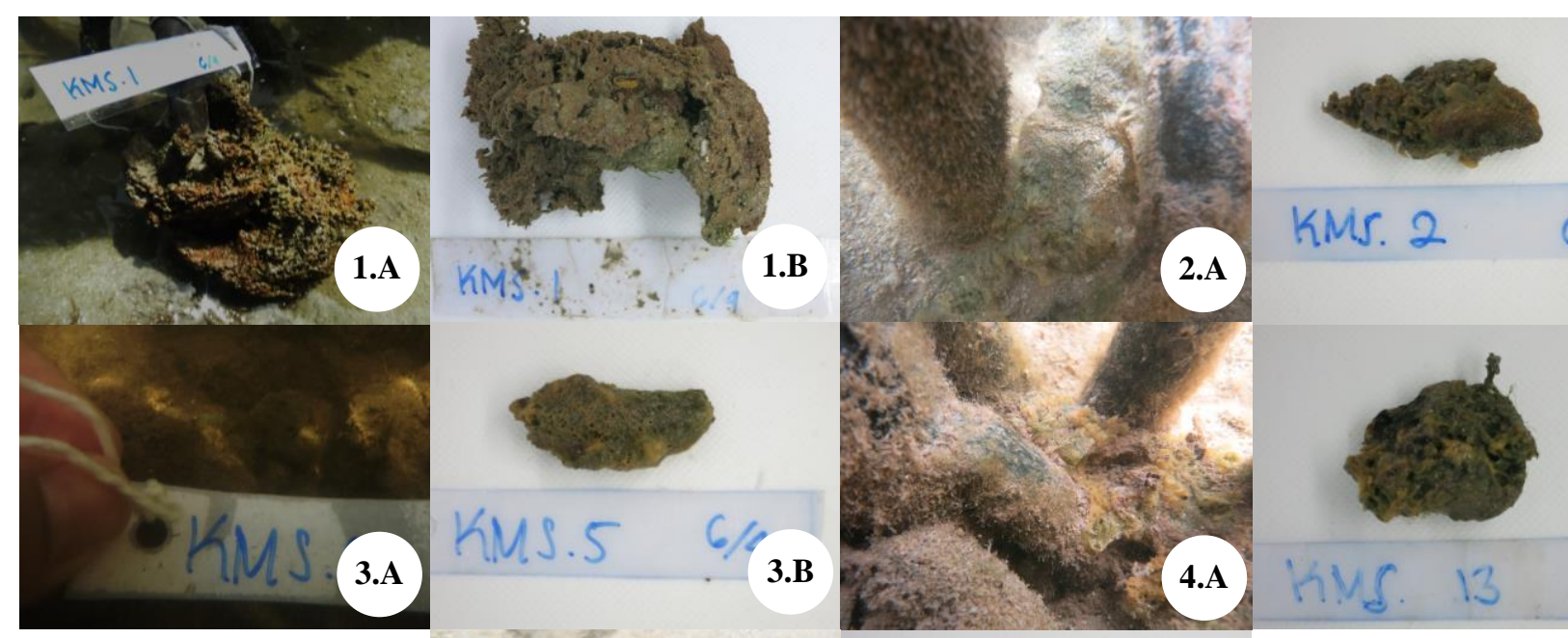

2.B

3.B
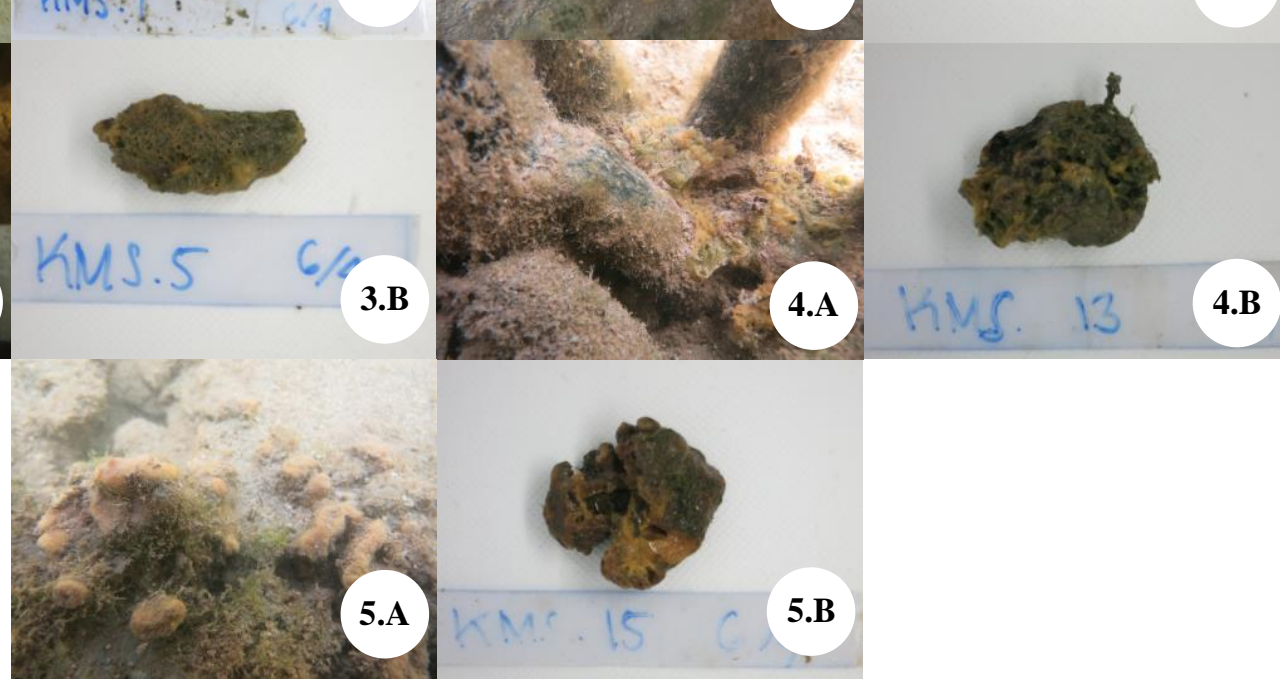

Figure 2. Habitat and morphology of mangrove-associated sponge in tracking mangrove Kemujan island, Karimunjawa National Park, Indonesia 
The sponge as a filter feeder collects the vegetative cells from the water; therefore, various fungal species have been discovered from this marine invertebrate. Some might be consumed as food, while others might stay to establish a symbiotic relationship with the sponge (Kohlmeyer and Kohlmeyer 1979; Raghukumar 2017; Nguyen and Thomas 2018). Nevertheless, only a few studies successfully discovered the symbiotic relationship between sponge and its fungi (Maldonado et al. 2005; Calabon et al. 2019). In this study, a total of 56 fungi were isolated from five mangrove-associated sponges from Kemujan Island, Karimunjawa National Park. Colonial and morphological identifications led to 19 isolates for molecular identification (in Supplementary Data). Furthermore, the phylogenetic tree of these isolates is presented in Figure 3.

Molecular identification was performed through a fungal DNA barcoding approach. The isolates are members of nine genera, namely Absidia, Aspergillus, Aureobasidium, Fusarium, Lasiodiplodia, Montagnula, Pestaliopsis, Trichoderma, and Wallemia, which share 93.61-100\% percent identity similarity with fungal species in GenBank (NCBI) according to ITS analysis. Furthermore, they belong to 7 genera from the phylum Ascomycota $(77.78 \%)$, one genus from the phylum Basidiomycota $(11.11 \%)$, and one genus from the phylum Mucoromycota $(11.11 \%)$. The diversity and abundance of sponge-associated fungi from Indonesia are still barely reported. Figure 4 shows that our works discovered that Trichoderma (n: 15, 26.79\%) was the most dominant genus, followed by Aspergillus (n: 13, 23.21\%) and Fusarium (n: 12, 21.43\%). These three genera have been well known as cosmopolitan fungi (Gal-Hemed et al. 2011; Benoit et al. 2013; Imhoff 2016; Abdel-Azeem et al. 2019). They produce an abundance of aerial vegetative cells easily brought by the wind, water, and other biological agents. Further, Aureobasidium (n: 5, 8.93\%) and Pestalotiopsis (n: 5, 8.93\%) had a same relative abundance value, followed by Absidia (n: 3, 5.36\%). It was noted that Lasiodiplodia, Montagnula, and Wallemia only had one species for each with a relative abundance value of $1.79 \%$. Several genera have been reported as sponge-associated fungi such as Aspergillus, Aureobasidium, Fusarium, Lasiodiplodia, Pestalotiopsis, Trichoderma (Calabon et al. 2019; Sibero et al. 2019). However, Absidia and Wallemia are less reported as sponge-associated fungi (Liu et al. 2010; Bovio et al. 2018; Chalearmsrimuang et al. 2019).

The overall frequency of occurrence (FOC) is shown in Table 2. Moreover, this study noted that Fusarium sp. MGKMS 13.4.1 was the most dominant species with a total FOC of $10.71 \%$, followed by A. pullulans PKMS 2.2 (FOC 8.93\%), P. microspora MKMS 2.5 .1 (FOC 8.93\%), $T$. longibrachiatum MKMS 15.1 (FOC $8.93 \%$ ), and T. reesei MKMS 5.1 (FOC 8.93\%). Interestingly, all genera of the isolated sponge-associated fungi are noted as marinederived fungi, and none of them was reported as marine obligate fungi. Marine-derived fungi adapt to the saline environment by modifying their cell wall, controlling gene expression (e.g., hydrophobin genes) to control the osmotic pressure, and regulating the water homeostasis during the increase of salinity (Fang et al. 2014; Pang et al. 2020; Pérez-Llano et al. 2020).

The diversity of sponge-associated fungi was calculated using the Shannon index $\left(\mathrm{H}^{\prime}\right)$ and Simpson index of dominance (1/D) (Calabon et al. 2019). The Simpson index of dominance (1/D) is significantly related to species evenness, while the Shannon index $\left(\mathrm{H}^{\prime}\right)$ is related to species richness (Johnson and Burnet 2016). It was noted that mangrove-associated sponge KMS 2 possessed the highest Shannon index value of $0.35\left(\mathrm{H}^{\prime}\right)$ and lowest Simpson index of dominance with a value of 14.67 (Table 2). In contrast, sponge KMS 5 had the lowest $\mathrm{H}^{\prime}$ value and highest 1/D value. Calabon et al. (2019) stated that a higher $\mathrm{H}^{\prime}$ value means a higher diversity while a higher $1 / \mathrm{D}$ value means a lower diversity. Therefore, the sponge KMS 2 had the highest fungal diversity and the lowest fungal diversity owned by sponge KMS 5. Furthermore, the Shannon index of evenness $\left(J^{\prime}\right)$ calculation gave the highest value to KMS 2 (1.0), then followed by KMS 1 (0.93), KMS 15 (0.90), KMS 13 (0.87), then KMS 5 (0.78) had the lowest value. On the other hand, Simpson index of evenness (E1/D) calculation gave a different result due to the highest value belonging to KMS 5 (6.87), followed by KMS 13 (3.42), KMS 15 (2.54), KMS 1 (1.94), and the lowest was possessed by KMS 2 (0.98). The lower $\mathbf{J}$ ' value indicates less evenness in communities between the species (Pielou 1966). Further, Smith and Wilson (1996) stated that evenness calculation using E1/D had some advantages, such as it has a strong relation with diversity and can reach the minimum of zero in any number of species. The higher $E 1 / \mathrm{D}$ value means the lower evenness in communities between species. Jaccard index of similarity was calculated to understand the species similarity between two sponge hosts (Table 3). Our data suggested that the highest similar fungal species were found between sponge KMS 1 and KMS 15 with a value of 0.73 . It means fungi isolated from KMS 1 were highly similar to the fungi hosted by sponge KMS 15 . On the other hand, fungi from KMS 5 were very distinct from the fungi isolated from sponge KMS 2.

There are three categories of cultivable fungi in sponges: sponge-generalist, sponge-associated, and spongespecialist ( $\mathrm{Li}$ and Wang 2009). Table 4 presents the association analysis of cultivable sponge-associated fungi. Our data suggested that Aspergillus, Aureobasidium, Fusarium, and Trichoderma could be defined as spongegeneralist since they were isolated from all mangroveassociated sponges. This result is in line with several studies that also emphasized Aspergillus as a spongegeneralist; however, Aureobasidium has never been reported as a sponge-generalist, while Trichoderma and Fusarium have been known as sponge-associates in a previous study (Li and Wang 2009; Menezes et al. 2010; Calabon et al. 2019). Absidia and Pestalotiopsis were isolated from multiple mangrove-associated sponges; hence, they were classified as sponge-associates. 
Table 2. The overall frequency of occurrence (FOC) of sponges-associated fungi from mangrove habitats in Kemujan Island, Central Java, Indonesia

\begin{tabular}{|c|c|c|c|c|c|c|c|c|c|c|c|c|}
\hline \multirow[b]{2}{*}{ Species } & \multicolumn{2}{|c|}{ KMS1 } & \multicolumn{2}{|c|}{ KMS2 } & \multicolumn{2}{|c|}{ KMS5 } & \multicolumn{2}{|c|}{ KMS13 } & \multicolumn{2}{|c|}{ KMS15 } & \multirow[b]{2}{*}{$\begin{array}{l}\text { Total no. of } \\
\text { occurrence }\end{array}$} & \multirow{2}{*}{$\begin{array}{c}\text { Total } \\
\text { FOC } \\
(\%)\end{array}$} \\
\hline & $\begin{array}{c}\text { No. of } \\
\text { occurrence }\end{array}$ & $\begin{array}{c}\text { FOC } \\
(\%)\end{array}$ & $\begin{array}{c}\text { No. of } \\
\text { occurrence }\end{array}$ & $\begin{array}{c}\text { FOC } \\
(\%)\end{array}$ & $\begin{array}{c}\text { No. of } \\
\text { occurrence }\end{array}$ & $\begin{array}{c}\text { FOC } \\
(\%)\end{array}$ & $\begin{array}{c}\text { No. of } \\
\text { occurrence }\end{array}$ & $\begin{array}{c}\text { FOC } \\
(\%)\end{array}$ & $\begin{array}{c}\text { No. of } \\
\text { occurrence }\end{array}$ & $\begin{array}{c}\text { FOC } \\
(\%)\end{array}$ & & \\
\hline Absidia repens MGKMS 2.3 & 1 & 25 & 1 & 25 & 0 & 0 & 0 & 0 & 1 & 25 & 3 & 5.36 \\
\hline Aspergillus flavus PKMS 1.4 & 1 & 25 & 0 & 0 & 0 & 0 & 0 & 0 & 1 & 25 & 2 & 3.57 \\
\hline Aspergillus niger PKMS 1.5 & 1 & 25 & 0 & 0 & 1 & 25 & 1 & 25 & 1 & 25 & 4 & 7.14 \\
\hline Aspergillus tubingensis MGKMS 1.1 & 0 & 0 & 1 & 25 & 0 & 0 & 0 & 0 & 0 & 0 & 1 & 1.79 \\
\hline Aspergillus unguis PKMS 13.3 & 1 & 25 & 1 & 25 & 0 & 0 & 0 & 0 & 1 & 25 & 3 & 5.36 \\
\hline Aspergillus versicolor MKMS 15.3 & 1 & 25 & 0 & 0 & 0 & 0 & 2 & 50 & 0 & 0 & 3 & 5.36 \\
\hline Aureobasidium pullulans PKMS 2.2 & 1 & 25 & 1 & 25 & 1 & 25 & 1 & 25 & 1 & 25 & 5 & 8.93 \\
\hline Fusarium keratoplasticum PKMS 1.4 & 2 & 50 & 1 & 25 & 1 & 25 & 0 & 0 & 0 & 0 & 4 & 7.14 \\
\hline Fusarium solani MGKMS 1.2 & 0 & 0 & 1 & 25 & 0 & 0 & 1 & 25 & 0 & 0 & 2 & 3.57 \\
\hline Fusarium sp. MGKMS 13.4.1 & 1 & 25 & 2 & 50 & 1 & 25 & 1 & 25 & 1 & 25 & 6 & 10.71 \\
\hline Lasiodiplodia theobromae MKMS 2.1.2 & 0 & 0 & 0 & 0 & 1 & 25 & 0 & 0 & 0 & 0 & 1 & 1.79 \\
\hline Montagnula scabiosae PKMS 13.1 & 0 & 0 & 1 & 25 & 0 & 0 & 0 & 0 & 0 & 0 & 1 & 1.79 \\
\hline Pestalotiopsis microspora MKMS 2.5.1 & 0 & 0 & 1 & 25 & 2 & 50 & 0 & 0 & 2 & 50 & 5 & 8.93 \\
\hline Trichoderma citrinoviride MGKMS 2.1.1 & 0 & 0 & 0 & 0 & 0 & 0 & 1 & 25 & 0 & 0 & 1 & 1.79 \\
\hline Trichoderma harzianum MKMS 15.1 & 1 & 25 & 2 & 50 & 0 & 0 & 1 & 25 & 1 & 25 & 5 & 8.93 \\
\hline Trichoderma longibrachiatum MKMS 5.1 & 1 & 25 & 1 & 25 & 0 & 0 & 1 & 25 & 2 & 50 & 5 & 8.93 \\
\hline Trichoderma sp. PKMS 5.3 & 0 & 0 & 1 & 25 & 0 & 0 & 0 & 0 & 0 & 0 & 1 & 1.79 \\
\hline Trichoderma virens MGKMS 15.3 & 1 & 25 & 0 & 0 & 1 & 25 & 1 & 25 & 0 & 0 & 3 & 5.36 \\
\hline Wallemia sp. MKMS 2.1 & 0 & 0 & 1 & 25 & 0 & 0 & 0 & 0 & 0 & 0 & 1 & 1.79 \\
\hline Total per sponge & 12 & & 15 & & 8 & & 10 & & 11 & & 56 & \\
\hline Shannon index of diversity (H') & 0.33 & & 0.35 & & 0.27 & & 0.30 & & 0.31 & & & \\
\hline Simpson index of diversity (D) & 0.04 & & 0.07 & & 0.02 & & 0.03 & & 0.03 & & & \\
\hline Simpson index of diversity (1/D) & 23.33 & & 14.67 & & 55.00 & & 34.22 & & 28.00 & & & \\
\hline Shannon index of evenness $\left(\mathrm{J}^{\prime}\right)$ & 0.93 & & 1.00 & & 0.79 & & 0.87 & & 0.90 & & & \\
\hline Simpson index of evenness (E1/D) & 1.94 & & 0.98 & & 6.87 & & 3.42 & & 2.54 & & & \\
\hline
\end{tabular}




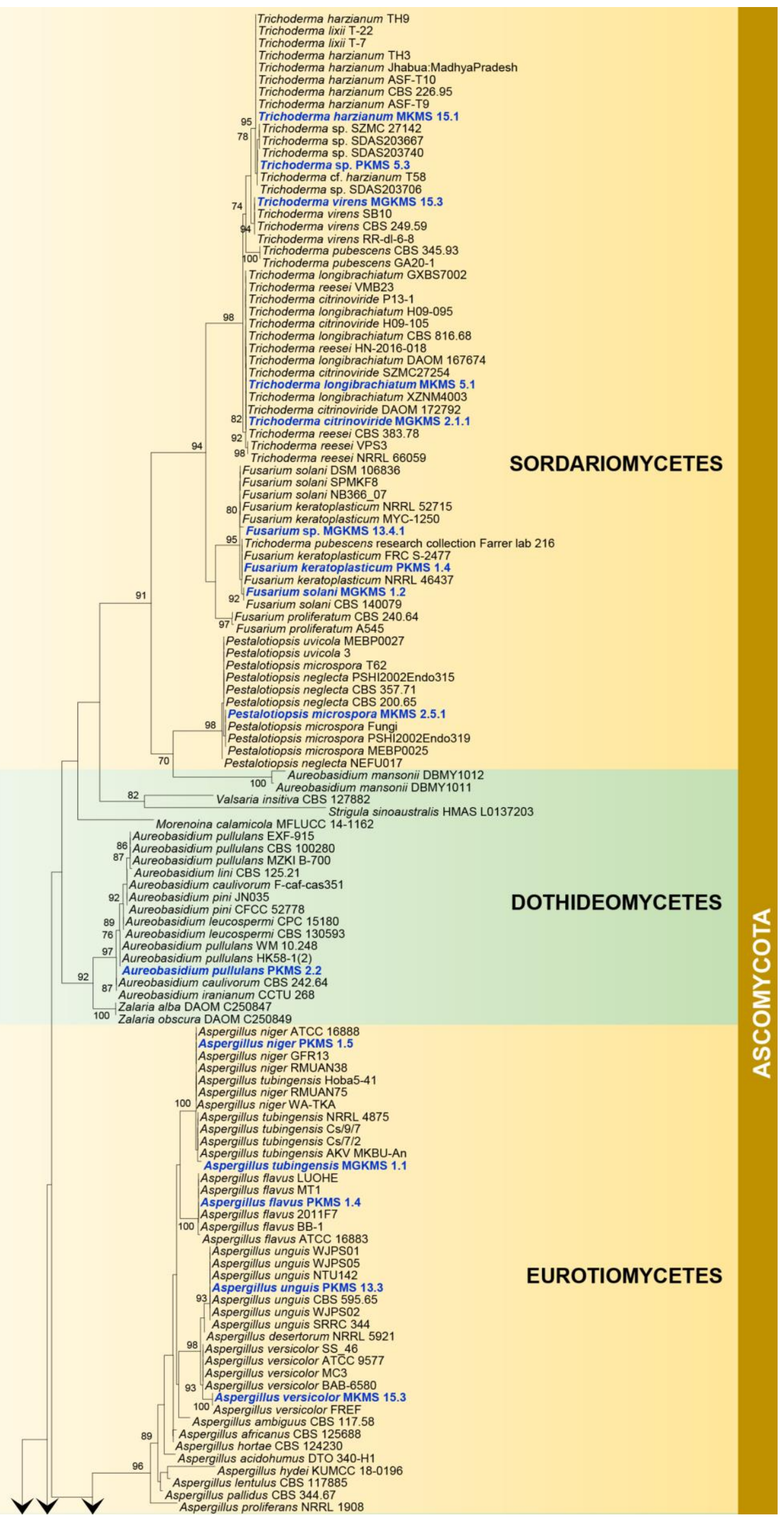




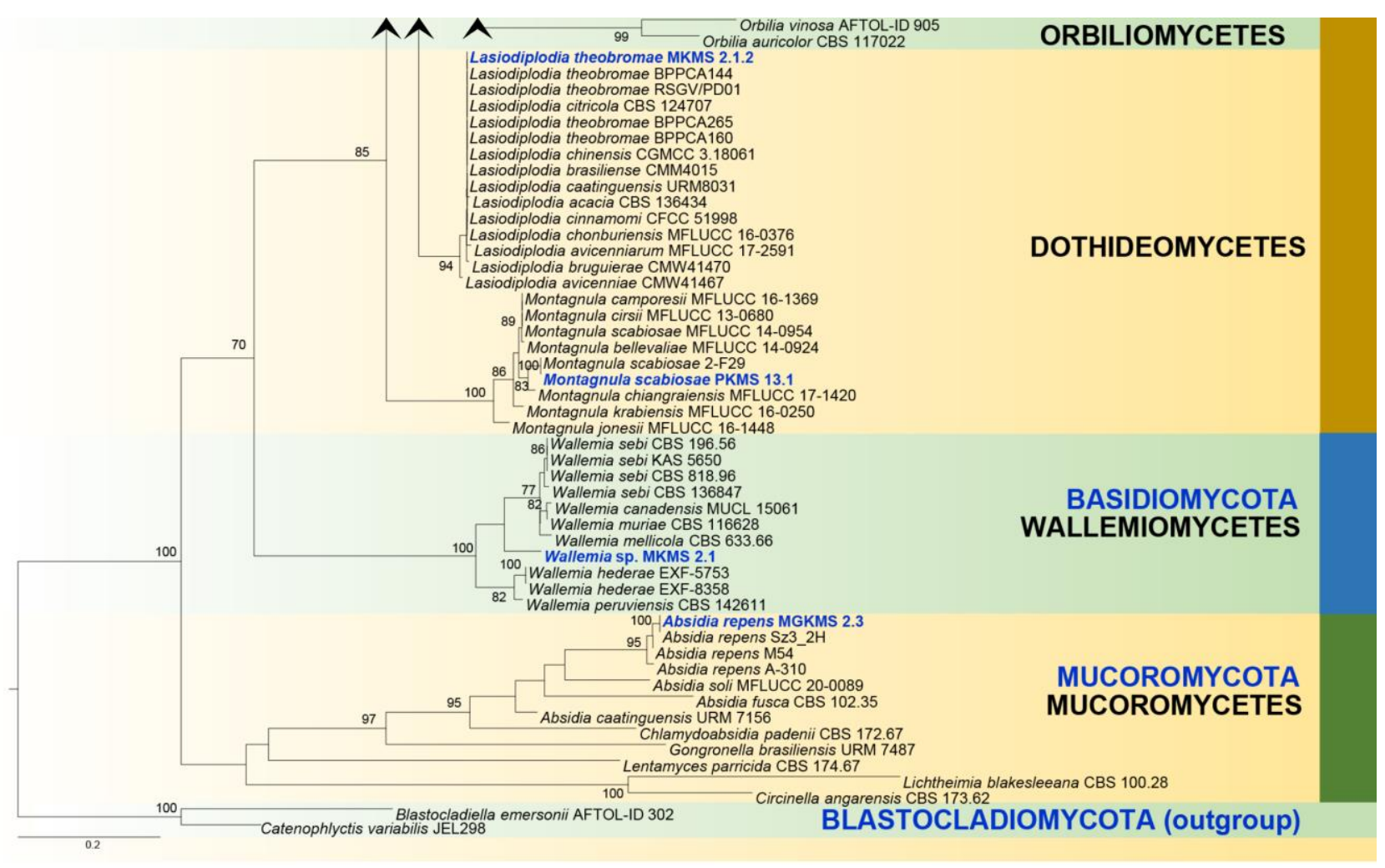

Figure 3. Phylogenetic tree generated from maximum likelihood (ML) analysis based on ITS sequence data for the species from Ascomycota, Basidiomycota, and Mucoromycota. Catenophlyctis variabilis (JEL298) and Blastocladiella emersonii (AFTOL-ID 302) were used as outgroup taxa. Bootstrap support values for ML equal to or greater than $75 \%$ are given above the nodes. The newly generated sequence is indicated in blue

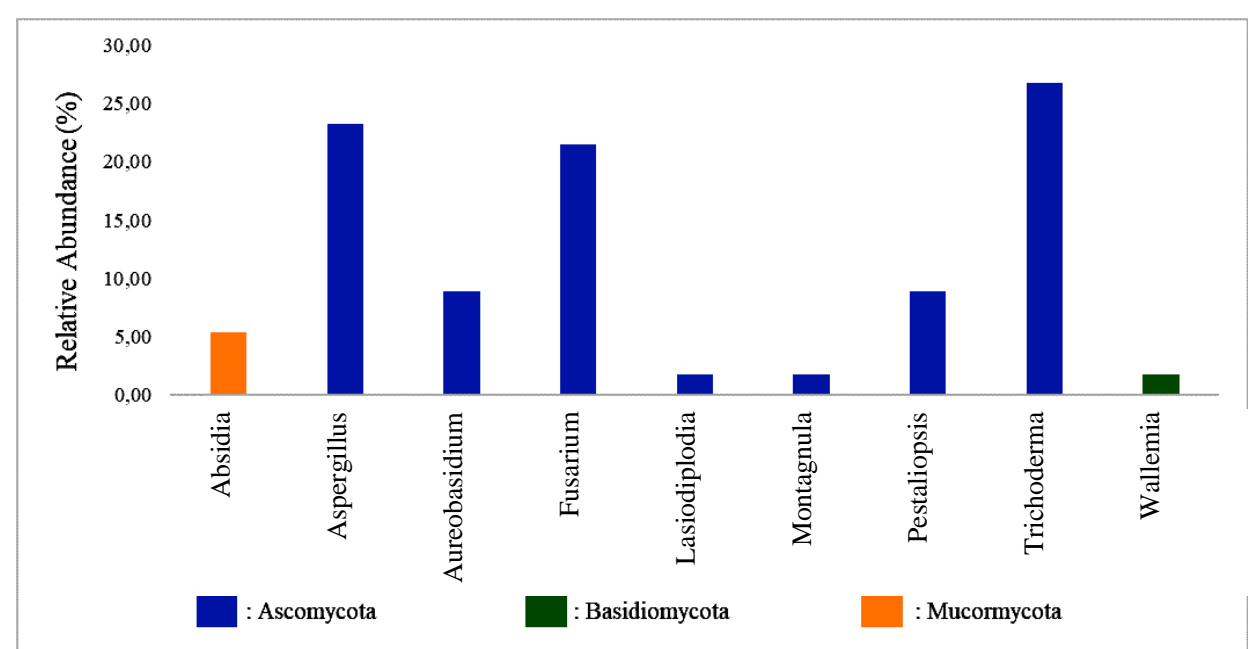

Figure 4. Relative abundance of fungal genera from mangrove-associated sponge collected from Kemujan island, Karimunjawa National Park, Central Java, Indonesia

Table 3. Jaccard index of similarity species among mangroveassociated sponge

\begin{tabular}{lccccc}
\hline Sponge & KMS 1 & KMS 2 & KMS 5 & KMS 13 & KMS 15 \\
\hline KMS 1 & & 0.41 & 0.36 & 0.54 & 0.73 \\
KMS 2 & 0.41 & & 0.25 & 0.29 & 0.47 \\
KMS 5 & 0.36 & 0.25 & & 0.33 & 0.33 \\
KMS 13 & 0.54 & 0.29 & 0.33 & & 0.38 \\
KMS 15 & 0.73 & 0.47 & 0.33 & 0.38 & \\
\hline
\end{tabular}

On the other hand, the sponge-specialist would include Lasiodiplodia, Montagnula, and Wallemia since they only presented in one specific host. Our previous work has reported Lasiodiplodia theobromae as a sponge-associated fungus from a Semarang mangrove forest (Sibero et al. 2019) and Jones et al. (2015, 2019) listed this as filamentous marine fungus. Nonetheless, Wallemia is infrequently reported as sponge-associated fungi (Liu et al. 2010), and Montagnula is never reported from the marine environment. 
Table 4. Association analysis of cultivable sponge-associated fungi

\begin{tabular}{lcccccc}
\hline \multirow{2}{*}{ Fungal genera } & \multicolumn{9}{c}{ Mangrove-associated sponge } & \multirow{2}{*}{ Proposed association } \\
\cline { 2 - 5 } & KMS 1 & KMS 2 & KMS 5 & KMS 13 & KMS 15 & Sponge-associates \\
Absidia & $\times$ & $\times$ & & & $\times$ & Sponge-generalist \\
Aspergillus & $\times$ & $\times$ & $\times$ & $\times$ & $\times$ & Sponge-generalist \\
Aureobasidium & $\times$ & $\times$ & $\times$ & $\times$ & $\times$ & Sponge-generalist \\
Fusarium & $\times$ & $\times$ & $\times$ & & Sponge-specialist \\
Lasiodiplodia & & $\times$ & $\times$ & & Sponge-specialist \\
Montagnula & & $\times$ & $\times$ & $\times$ & Sponge-associates \\
Pestalotiopsis & & $\times$ & & & Sponge-generalist \\
Trichoderma & $\times$ & $\times$ & & & Sponge-specialist \\
Wallemia & & $\times$ & & &
\end{tabular}

Note: " $x$ " indicates the presence of particular genera

Montagnula spp. has been widely reported as plantassociated fungi, where M. scabiosae was first isolated from Scabiosa sp. flower (Hongsanan et al. 2015; Tennakoon et al. 2016). The fact that M. scabiosae is a plant-associated fungus leads to a presumption that it lived inside the mangrove, then the spores fell into the water and were filtered by the sponge. We can also assume that $M$. scabiosae can be found in terrestrial and aquatic habitats and thrives on different hosts.

Moreover, previous studies have proven that the sponge and the seawater surrounding the sponge share several similar microorganisms, including the fungi (de Mares et al. 2017; Nguyen and Thomas 2018). Although three genera were isolated as a sponge specialists, further study is needed to support this result since there is no direct evidence to validate these fungi interaction with the host. In addition, the role of fungi in the sponge is still not clearly understood. Nguyen and Thomas (2018) stated that fungal communities in the sponge holobiont have less roles rather than the bacterial and archaeal symbionts. de Mares et al. (2017) stated that the fungal diversity in a sponge is determined by the host species and genus. Therefore, some fungi can only live in a specific species while others live as cosmopolitan fungi. In addition, the study of fungal recruitment in the sponge is barely understood. Yet, a previous study stated that unicellular fungus could be vertically transmitted via the oocytes in the Porifera (Maldonado et al. 2005).

In summary, this study successfully isolated 56 spongeassociated fungi from a mangrove forest in Kemujan Island, Karimunjawa National Park. Morphological characterization led to 19 fungal species that were expected as different species. DNA barcoding discover Trichoderma (n: 15, 26.79\%), Aspergillus (n: 13, 23.21\%) and Fusarium (n: 12, 21.45\%) were the top three dominant genera among all isolates. This study also reported that Aspergillus, Aureobasidium, Fusarium, and Trichoderma could be defined as sponge-generalist; Absidia and Pestalotiopsis as sponge-associates; while Lasiodiplodia, Montagnula, and Wallemia as sponge-specialist. Mangrove-associated sponge KMS 2 possessed the highest Shannon index value of $0.35\left(\mathrm{H}^{\prime}\right)$ and lowest Simpson index of dominance with a value of 14.67 .

\section{ACKNOWLEDGEMENTS}

This article is an outcome of a research grant funded by the Faculty of Fisheries and Marine Science, Universitas Diponegoro year 2019, granted to Dr. Rudhi Pribadi with contract number 39/UN7.5.10/PP/2019. This study was also supported by the RPIBT Research Scheme that fund by Universitas Diponegoro to Dr. Mada Triandala Sibero with contract number 185-96/UN7.6.1/PP/2021. We also thank to Balai Taman Nasional Karimunjawa who give us permission with permit no. 1276/T.34/TU/SIMAKSI/ 04/2019. MS Calabon is grateful to the Department of Science and Technology - Science Education Institute (Philippines) and Mushroom Research Foundation.

\section{REFERENCES}

Abdel-azeem AM, Abdel-azeem MA, Darwish AG, Nafady NA, Ibrahim NA. 2019. Fusarium: Biodiversity, ecological significances, and industrial applications. In: Yadav AN, Mishra S, Singh S, Gupta A (eds). Recent Advancement in White Biotechnology Through Fungi. Springer Nature, Switzerland.

Becking LE, Cleary DFR, de Voogd NJ. 2013. Sponge species composition, abundance, and cover in marine lakes and coastal mangroves in Berau, Indonesia. Mar Ecol Prog Ser 481: 105-120. DOI: $10.3354 /$ meps 10155 .

Bell JJ, Jompa J, Haris A, Werorilangi S, Shaffer M, Mortimer C. 2019. Domination of mesophotic ecosystems in the Wakatobi Marine National Park (Indonesia) by sponges, soft corals and other non-hard coral species. J Mar Biol Assoc U K 99 (4): 771-775. DOI: 10.1017/S0025315418000917.

Benoit I, Malavazi I, Goldman GH, Baker SE, de Vries RP. 2013. Aspergillus: Genomics of a cosmopolitan fungus. In: Horwitz BA, Mukherjee PK, Mukherjee M, Kubicek CP (eds). Genomics of Soiland Plant-Associated Fungi. Springer Nature, Switzerland.

Bovio E, Garzoli L, Poli A, Prigione V, Firsova D, McCormack GP, Varese GC. 2018. The culturable mycobiota associated with three Atlantic sponges, including two new species: Thelebolus balaustiformis and T. spongiae. Fungal Syst Evol 1: 141-167. DOI: 10.3114\%2Ffuse.2018.01.07.

Bovio E, Garzoli L, Poli A, Luganini A, Villa P, Musumeci R, McCormack GP, Cocuzza CE, Gribaudo G, Mehiri M, Varese GC. 2019. Marine fungi from the sponge Grantia compressa: Biodiversity, chemodiversity, and biotechnological potential. Mar Drugs 17 (4): 220. DOI: 10.3390\%2Fmd17040220.

Calabon MS, Sadaba RB, Campos WL. 2019. Fungal diversity of mangrove-associated sponges from New Washington, Aklan, Philippines. Mycology 10 (1): 6-21. DOI: 10.1080/21501203.2018.1518934.

Calcinai B, Bastari A, Makapedua DM, Cerrano C. 2017. Mangrove sponges from Bangka Island (North Sulawesi, Indonesia) with the 
description of a new species. J Mar Biol Assoc U K 97 (6): $1417-$ 1422. DOI: $10.1017 / \mathrm{S} 0025315416000710$.

Chakraborty SK. 2019. Bioinvasion and environmental perturbation: Synergistic impact on coastal-mangrove ecosystems of West Bengal, India. In: Makowski C, Finkl C (eds). Impacts of Invasive Species on Coastal Environments. Coastal Research Library, vol 29. Springer, Cham.

Chalearmsrimuang T, Ismail SI, Mazlan N, Suasaard S, Dethoup T. 2019. Marine-derived fungi: A promising source of halo tolerant biological control agents against plant pathogenic fungi. J Pure Appl Microbiol 13 (1): 209-223. DOI: 10.22207/JPAM.13.1.22.

de Mares MC, Sipkema D, Huang S, Bunk B, Overmann J, Elsas JDV. 2017. Host specificity for bacterial, archaeal and fungal communities determined for high- and low-microbial abundance sponge species in two genera. Front Microbiol 8: 2560. DOI: 10.3389/fmicb.2017.02560.

Després VR, Huffman JA, Burrows SM, Hoose C, Safatov AS, Buryak G, Nowoisky JF, Elbert W, Andreae MO, Pöschl U, Janicke R. 2012. Primary biological aerosol particles in the atmosphere: A review. Tellus B: Chem Phys Meteorol 64 (1): 15598. DOI: 10.3402/tellusb.v64i0.15598

Dissanayake AJ, Bhunjun CS, Maharachchikumbura SSN, Liu JK. 2020. Applied aspects of methods to infer phylogenetic relationships amongst fungi. Mycosphere 11 (1): 2652-2676. DOI: $10.5943 /$ mycosphere/11/1/18

Fang J, Han X, Xie L, Liu M, Qiao G, Jiang J, Zhuo R. 2014. Isolation of salt stress-related genes from Aspergillus glaucus CCHA by random overexpression in Escherichia coli. Sci World J 2014: 620959. DOI: $10.1155 / 2014 / 620959$

Gal-Hemed I, Atanasova L, Komon-Zelazowska M, Druzhinina IS, Viterbo A, Yarden O. 2011. Marine isolates of Trichoderma spp. As potential halotolerant agents of biological control for arid-zone agriculture. Appl Environ Microbiol 77 (15): 5100-5109. DOI: 10.1128/AEM.00541-11

González-Rivero M, Yakob L, Mumby PJ. 2011. The role of sponge competition on coral reef alternative steady states. Ecol Modell 222 (11): 1847-1853. DOI: 10.1016/j.ecolmodel.2011.03.020.

Hapsari RW, Hartoko A, Hendrarto B. 2020. Mangrove vulnerability index and carbon algorithm using sentinel-2a satellite data at Kemujan Island, Karimunjawa Islands, Indonesia. AACL Bioflux 13 (3): 1453-1462.

Harris JL. 2000. Letter to the editor: Safe, low-distortion tape touch method for fungal slide mounts. J Clin Microbiol 38 (12): 4683-4684. DOI: $10.1128 / \mathrm{jcm} .38 .12 .4683-4684.2000$

Hongsanan S, Hyde KD, Bahkali AH, Camporesi E, Chomnunti P, Ekanayaka H, Gomes AAM, Hofstetter V, Jones EBG, Pinho DB, Pereira OL, Tian Q, Wanasinghe DN, Xu JC, Buyck B. 2015. Fungal biodiversity profiles 11-20. Cryptogam Mycol 36 (3): 355-380. DOI: 10.7872/crym/v36.iss3.2015.355

Imhoff JF. 2016. Natural products from marine fungi-still an underrepresented resource. Mar Drugs 14 (1): $19 . \quad$ DOI $10.3390 / \mathrm{md} 14010019$.

Indraningrat AAG, Smidt H, Sipkema D. 2016. Bioprospecting spongeassociated microbes for antimicrobial compounds. Mar Drugs 14 (5) 87. DOI: $10.3390 / \mathrm{md} 14050087$.

Indrayanti E, Zainuri M, Sabdono A, Wijayanti DP, Pranowo WS, Siagian HSR. 2019. Larval dispersal model of coral acropora in the Karimunjawa Waters, Indonesia. Biodiversitas 20 (7): 2068-2075. DOI: 10.13057/biodiv/d200738.

Ismet MS, Bengen DG, Setianingsih WA, Yudhani BA, Nati NMN. 2020. Associative-mesofauna abundance and its correlation with sponges antibacterial activity in seagrass ecosystem. The 4th EMBRIO International Symposium and the 7th International Symposium of East Asia Fisheries and Technologists Association. IPB University, Bogor, 5-6 August 2019. [Indonesian]

Johnson KVA, Burnet PWJ. 2016. Microbiome: Should we diversify from diversity? Gut Microbes 7 (6): 455-458. DOI: 10.1080/19490976.2016.1241933.

Jones EBG, Pang KL, Abdel-wahab MA, Scholz B, Hyde KD, Boekhout T, Ebel R, Rateb ME, Henderson L, Sakayaroj J, Seutrong S, Dayarathne MC, Kumar V, Raghukumar S, Sridhar KR, Bahkali AHA, Gleason FH, Norphanphoun C. 2019. An online resource for marine fungi. Fungal Divers 96: 347-433. DOI: 10.1007/s13225-01900426-5.

Jones EBG, Seutrong S, Sakayaroj J, Bahkali AH, Abdel-wahab MA, Boekhout T, Pang K-L. 2015. Classification of marine Ascomycota,
Basidiomycota, Blastocladiomycota and Chytridiomycota. Fungal Divers 73: 1-72. DOI: 10.1007/s13225-015-0339-4.

Kamal M, Hartono H, Wicaksono P, Adi NS, Arjasakusuma S. 2016. Assessment of mangrove forest degradation through canopy fractional cover in Karimunjawa Island, Central Java, Indonesia. Geoplanning: J Geomat Plann 3 (2): 107-116. DOI: 10.14710/geoplanning.3.2.107116.

Kohlmeyer J, Kohlmeyer E. 1979. Marine Mycology: The Higher Fungi. Academic Press, New York.

Li Q, Wang G. 2009. Diversity of fungal isolates from three Hawaiian marine sponges. Microbiol Res 164 (2): 233-241. DOI: 10.1016/j.micres.2007.07.002

Liu WC, Li CQ, Zhu P, Yang JL, Cheng KD. 2010. Phylogenetic diversity of culturable fungi associated with two marine sponges: Haliclona simulans and Gelliodes carnosa, collected from the Hainan Island coastal waters of the South China Sea. Fungal Divers 42: 1-15. DOI: 10.1007/s13225-010-0022-8.

Ludwig JA, Reynolds JF. 1988. Statistical Ecology: A Primer on Methods and Computing. John Wiley \& Sons, Inc., New Jersey.

Maldonado M, Cortadellas N, Trillas MA, Rützler K. 2005. Endosymbiotic yeast maternally transmitted in a marine sponge. Biol Bull 209 (2): 94-106. DOI: 10.2307/3593127.

Menezes CBA, Bonugli-santos RC, Miqueletto PB, Passarini MRZ, Silva CHD, Justo MR, Leal RR, Fantinatti-Garboggini F, Oliveira VM, Berlinck RGS, Sette LD. 2010. Microbial diversity associated with algae, ascidians and sponges from the North Coast of São Paulo State, Brazil. Microbiol Res 165 (6): 466-482. DOI: 10.1016/j.micres.2009.09.005.

Nehren U, Wicaksono P. 2018. Mapping soil carbon stocks in an oceanic mangrove ecosystem in Karimunjawa Islands, Indonesia. Estuar Coast Shelf Sci 214: 185-193. DOI: 10.1016/j.ecss.2018.09.022.

Nguyen MTHD, Thomas T. 2018. Diversity, host-specificity and stability of sponge-associated fungal communities of co-occurring sponges. PeerJ 2018 (6): 1-26. DOI: 10.7717/peerj.4965.

Pang KL, Chiang MWL, Guo SY, Shih CY, Dahms HU, Hwang JS, Cha HJ. 2020. Growth study under combined effects of temperature, ph and salinity and transcriptome analysis revealed adaptations of Aspergillus terreus NTOU4989 to the extreme conditions at Kueishan Island hydrothermal vent field, Taiwan. Plos One 15 (5): e0233621. DOI: 10.1371 /journal.pone.0233621

Pérez-llano Y, Rodríguez-pupo EC, Druzhinina IS, Chenthamara K, Cai F, Gunde-cimerman N, Zalar P, Gostinčar C, Kostanjšek R, Folchmallol JL, Batista-garcía RA, Sánchez-carbente MR. 2020. Stress reshapes the physiological response of halophile fungi to salinity. Cells 9 (3): 1-21. DOI: $10.3390 \% 2 F c e l l s 9030525$.

Pielou EC. 1966. The measurement of diversity in different types of biological collections. J Theor Biol 13 (C): 131-144. DOI: 10.1016/0022-5193(66)90013-0.

Pita L, Rix L, Slaby BM, Franke A, Hentschel U. 2018. The sponge holobiont in a changing ocean: From microbes to ecosystems. Microbiome 6 (1): 46. DOI: 10.1186/s40168-018-0428-1.

Puryono S, Suryanti S. 2019. Degradation of mangrove ecosystem in Karimunjawa Island based on public perception and management. The $4^{\text {th }}$ International Conference on Tropical and Coastal Region Eco Development. Universitas Diponegoro, Semarang, 30-31 October 2018

Raghukumar S. 2017. Fungi in Coastal And Oceanic Marine Ecosystems: Marine Fungi in Coastal and Oceanic Marine Ecosystem. Springer Nature, Switzerland.

Riddell RW. 1950. Permanent stained mycological preparationsobtained by slide culture. Mycologia 42: 265-270. DOI: 10.2307/3755439.

Sabdaningsih A, Liu Y, Mettal U, Heep J, Riyanti, Wang L, Cristianawati O, Nuryadi H, Sibero MT, Marner M, Radjasa OK, Sabdono A, Trianto A, Schäberle TF. 2020. A new citrinin derivative from the Indonesian. Mar Drugs 18 (4): 227. DOI: 10.3390/md18040227.

Setiawan E, Muzaki FK, Ashuri NM. 2018. Shallow water sponges that associated to mangrove ecosystem at Labuhan conservation area in Sepulu, Bangkalan, Madura, East Java Province. Niche J Trop Biol 1 (2): 19-29. DOI: 10.14710/niche.1.2.19-29

Setiawan E, Muzaki FK, Nurhayati APD, Maulidina N. 2019. Record of shallow-water sponges in Simeulue Island, Aceh Province, Indonesia. Biodiversitas 20 (11): 3246-3257. DOI: 10.13057/biodiv/d201117.

Sibero MT, Radjasa OK, Sabdono A, Trianto A, Triningsih DW, Hutagaol ID. 2018. Antibacterial activity of Indonesian sponge associated fungi against clinical pathogenic multidrug resistant bacteria. J Appl Pharm Sci 8 (2): 088-094. DOI: 10.7324/JAPS.2018.8214. 
Sibero MT, Igarashi Y, Radjasa OK, Sabdono A, Trianto A, Zilda DS, Wijaya YJ. 2019. Sponge-associated fungi from a mangrove habitat in Indonesia: Species composition, antimicrobial activity, enzyme screening and bioactive profiling. Intl Aquat Res 11 (2): 173-186. DOI: $10.1007 / \mathrm{s} 40071-019-0227-8$

Sibero MT, Zhou T, Fukaya K, Urabe D, Radjasa OKK, Sabdono A, Trianto A, Igarashi Y. 2019. Two new aromatic polyketides from a sponge-derived Fusarium. Beilstein J Org Chem 15: 2941-2947. DOI: $10.3762 /$ bjoc. 15.289 .

Sibero MT, Zhou T, Igarashi Y, Radjasa OK, Sabdono A, Trianto A, Bachtiarini TU, Bahry MS. 2020. Chromanone-type compounds from marine sponge-derived Daldinia eschscholtzii KJMT FP 4.1. J Appl Pharm Sci 10 (1): 1-7. DOI: 10.7324/JAPS.2020.101001.

Smith B, Wilson JB. 1996. A consumer's guide to evenness indices. Oikos 76: 70-82. DOI: $10.2307 / 3545749$.
Tennakoon DS, Hyde KD, Wanasinghe DN, Bahkali AH, Camporesi E, Khan S, Phookamsak R. 2016. Taxonomy and phylogenetic appraisal of Montagnula jonesii sp. Nov. (Didymosphaeriaceae, Pleosporales). Mycosphere 7 (9): 1346-1356. DOI: 10.5943/mycosphere/7/9/8.

Vahidi F, Fatemi SMR, Danehkar A, Mashinchian A, Nadushan RM. 2020. Benthic macrofaunal dispersion within different mangrove habitats in Hara Biosphere Reserve, Persian Gulf. Intl J Environ Sci Technol 17 (3): 1295-1306. DOI: 10.1007/s13762-019-02469-2.

Winata A, Yuliana E, Hewindati YT, Djatmiko WA. 2020. Assessment of mangrove carrying capacity for ecotourism in Kemujan Island, Karimunjawa National Park, Indonesia. AES Biofux 12 (1): 83-97.

Yang Q, Zhang W, Franco CMM. 2019. Symbiotic Microbiomes of Coral Reefs Sponges and Corals Response of Sponge Microbiomes to Environmental Variations. Springer, Netherlands. 